\title{
Pengaruh Model Pembelajaran Daring Akibat Pandemi Covid- 19 Terhadap Prestasi Belajar Mahasiswa UNAI pada Semester Genap 2019/2020
}

\author{
Albinur Limbong \\ Fakultas Teknologi Informasi, Universitas Advent Indonesia \\ e-mail: alimbong@unai.edu
}

\begin{abstract}
Abstrak
Artikel ini adalah sebuah laporan studi tentang dampak dari perubahan yang tiba-tiba dalam model pembelajaran yang tadinya tatap muka di kelas menjadi daring, diakibatkan oleh pandemi covid-19, di Universitas Advent Indonesia tahun 2019/2020. Populasi dalam penelitian ini adalah semua mahasiswa yang mendaftar pada semester ganjil dan genap tahun 19/20, yang berjumlah 1516 orang, dan semua populasi menjadi sampel. Prestasi belajar mahasiswa hanya dilihat dari Indeks Prestasi Semester (IPS) yang dicapai oleh mahasiswa pada akhir semester yang diikuti. Secara umum untuk level universitas prestasi belajar mahasiswa meningkat, walau secara fakultas ada dua fakultas yang mengalami sedikit penurunan yaitu fakultas ekonomi dan Keguruan dan Ilmu Pendidikan, sedangkan fakultas lain mengalami kenaikan. Secara tingkat didapat bahwa yang mengalami dampak negative dari pembelajaran daring adalah mahasiswa baru (tingkat 1), sedangkan tingkat 2 dan seterusnya tidak mengalami masalah dalam prestasi, bahkan justru berdampak yang positif, dengan adanya peningkatan dalam IPS. Secara jenis kelamin didapat bahwa baik mahasiswa pria maupun wanita mengalami dampak positif pada prestasi belajar, namun rerata IPS pada wanita lebih besar dari pria. Hasil penelitian ini agak mengherankan karena tadinya diduga akan ada penurunan IPS mahasiswa akibat perubahan yang drastis dalam model pembelajaran dari tatap muka menjadi daring. Namun dari hasil ini disimpulkan Universitas Advent Indonesia cukup berhasil mengatasi kendala-kendala yang terjadi akibat perubahan pembelajaran tersebut, bahkan pandemi covid-19 berdampak positif pada prestasi belajar mahasiswa. Itu terjadi karena baik mahasiswa maupun dosen dapat bekerja sama untuk mengatasi setiap kendala yang terjadi dalam perubahan model pembelajaran. Hasil penelitian ini perlu dilanjutkan untuk melihat efek jangka panjang dari pembelajaran daring, apakah prestasi belajar terus meningkat atau tidak, dengan melihat hasil pembelajaran pada semester ganjil 2020/2021 yang akan datang.
\end{abstract}

Kata Kunci: Pembelajaran, daring, prestasi belajar, pandemi covid-19, dampak pembelajaran.

\section{The Effect of Online Learning Model due to Covid-19 Pandemic, on the Academic Achievement of UNAI Students in Even Semester $2019 / 2020$.}

\begin{abstract}
This article is a report of a study regarding the impact of a drastic change in learning model from face to face in class to become virtual class, due to covid-19 pandemic, in Universitas Advent Indonesia in academic year 2019/2020. The population for this study is all students enrolled both in the odd and even semester 2019/2020, i.e. 1516 students, and all population become sample. The academic achievement is seen solely by Semester Grade Point Average (GPA) achieved by the students in end of semester. Generally, at the university level, the academic achievement increased, although there are two faculties, i.e. Economics and Education, the academic achievement of students decreased slightly, while for other
\end{abstract}


faculties, the achievement increased. Based on the batch, the first year student showed a negative impact of daring system, while other batches performed positively. In terms gender, both male and female students have a positive impact of daring learning system, however female students performed better than male students. These results are surprising, since it was assumed before that the academic achievement will be decreased due to the drastic change in the learning model from class room model to virtual model. This study implied that the covid-19 pandemic brought a positive impact in the academic achievement of UNAI students. This happened since both faculties and students of UNAI were successful to overcome any difficulties or challenges in the learning model due to the covid-19 pandemic However, this study needs to be continued to see the long term observation, whether the positive impact still happens or not in the odd semester 2020/2021.

Keywords: Learning, online, learning achievement, covid-19 pandemic, impact of learning

\section{Pendahuluan}

Sejak awal tahun 2020 dunia dilanda sebuah pandemi virus corona, atau disingkat covid-19, yang sangat menakutkan dan telah memakan banyak korban. Selain membunuh manusia, pandemi ini juga merusak sendi-sendi perekonomian masyarakat dan dunia, dan telah mengganggu berbagai aspek kehidupan. Bahkan sejak awal Maret 2020 pemerintah Republik Indonesia telah menerapkan kebijakan lockdown, suatu kebijakan dimana orang diharuskan bekerja dari rumah, khususnya bagi daerah-daerah yang masuk zona kuning dan merah. Tidak terkecuali, dunia pendidikan di Indonesia mengalami suatu disrupsi dalam metode pembelajaran dari tatap muka di kelas menjadi daring (online). Hal ini dilakukan pemerintah dengan tujuan untuk menghentikan penyebaran virus corona.

Tidak terkecuali, Universitas Advent Indonesia yang menjalankan sebuah Pendidikan Tinggi berasrama, dimana seluruh mahasiswa yang datang dari berbagai daerah di Indonesia, bahkan ada juga dari luar negeri, diwajibkan tinggal di asrama, kecuali mereka yang tinggal bersama orangtuanya yang tempat tinggalnya dekat dengan kampus UNAI, dalam radius kurang dari 2 kilometer. Konsep kampus berasrama ini dijalankan karena UNAI sangat menekankan pembangunan karakter, sehingga pembangunan karakter akan berjalan maksimal jika mahasiswa tinggal di asrama yang disiapkan UNAI di dalam kampus, dengan luas area sekitar 23 hektar.

Berbeda dengan kampus berasrama yang umum lainnya, di UNAI mahasiswa tidak bebas keluar masuk kampus tanpa ijin. Namun sejak pandemi covid-19 UNAI tidak dapat menahan mahasiswa di dalam kampus, karena banyak orang tua mengkhawatirkan keselamatan anak-anak mereka selama lock-down, akibat pandemi covid-19. Sehingga hampir semua mahasiswa pulang ke rumah orang tua mereka. Dan sejak pertengahan Maret 2020 pembelajaran di UNAI harus dilakukan secara daring.

Sebelum Covid-19 semua pembelajaran di UNAI adalah tatap muka langsung di kelas. Walau fasilitas jaringan dan bandwidth internet sudah cukup memadai di kampus, namun UNAI tidak memiliki ijin melakukan Pendidikan Jarak Jauh (PJJ). Sebagian fakultas sudah menggunakan Moodle untuk manajemen kelas, namun belum ada menggunakan Zoom atau platform video conference lainnya untuk pembelajaran daring. Sehingga sejak pertengahan Maret 2020 terjadi perubahan yang sangat drastis dalam model pembelajaran. Siap atau tidak siap, mahasiswa dan dosen hanya diperbolehkan bertemu secara virtual. Setiap dosen dan mahasiswa dipaksa mengembangkan kreativitasnya untuk belajar dan mengajar secara virtual. Walaupun tim IT UNAI berusaha dengan waktu singkat melakukan pelatihan-pelatihan secara virtual bagi dosen untuk menggunakan fasilitas pembelajaran online yang berkembang secara tiba-tiba di kampus UNAI.

Tujuan penelitian ini dilakukan adalah untuk melihat apakah ada pengaruh perubahan yang tiba-tiba dalam model pembelajaran dari tatap muka di kelas menjadi daring, sebagai akibat dari pandemi covid-19, terhadap prestasi belajar mahasiswa UNAI pada tahun akademik 2019/2020. Dengan mengetahui ada tidak tidaknya pengaruh tersebut, apalagi kalau ada dampak negatifnya, maka dapat dibuat langkah-langkah strategis untuk mengatasinya. 


\section{Tinjauan Pustaka}

\section{Model Pembelajaran dan pengaruhnya pada prestasi belajar}

Tujuan utama pembelajaran adalah prestasi belajar yang maksimal. Prestasi belajar adalah hasil dari proses belajar mengajar. Proses belajar mengajar yang baik adalah proses belajar mengajar yang sesuai dengan harapan dari objek pembelajaran yaitu mahasiswa itu sendiri. Prestasi belajar akan maksimal jika faktor-faktor pendukung proses belajar mengajar terpenuhi. Faktor-faktor pendukung belajar mengajar antara lain faktor diri sendiri mahasiswa (inteligensi, bakat, minat, dll) juga oleh faktor luar (guru atau dosen), sarana dan prasarana belajar, dan faktor lingkungan belajar lainnya) [1-3].

Guru atau Dosen adalah bagian yang sangat penting dalam mempengaruhi mahasiswa untuk mencapai prestasi belajar yang maksimal. Proses belajar mengajar di kelas, kedekatan hubungan dosen dan mahasiswa di luar kelas sangat penting untuk mempengaruhi pencapaian akademik mahasiswa.

Prestasi belajar dapat juga dipengaruhi oleh metode pembelajaran yang digunakan oleh dosen [4]. Itu sebabnya seorang guru atau dosen harus menggunakan metode yang tepat untuk membuat pembelajaran tersebut menarik dan dapat dimengerti oleh siswa atau mahasiswa.

Beberapa studi telah dilakukan bagi mahasiswa di Indonesia untuk melihat dampak dari pembelajaran daring selama masa pandemi covid-19 terhadap mahasiswa, baik dari sisi dampak positif maupun negatifnya jika pembelajaran daring dilakukan dengan efektif memungkinan dosen dan mahasiswa berinteraksi dalam kelas virtual yang dapat diakses dimana saja dan kapan saja. Pembelajaran daring dapat membuat mahasiswa belajar mandiri dan motivasinya meningkat. Namun, ada kelemahan pembelajaran daring mahasiswa tidak terawasi dengan baik selama proses pembelajaran daring [5-6]. Pembelajaran Online pada masa pandemi covid-19 berdampak pada mental mahasiswa karena perubahan pembelajaran pada masa pandemi ini menimbulkan kecemasan. Timbulnya kecemasan dan perubahan mental dapat berdampak negatif terhadap proses pembelajaran dan hasil belajar [7-8].

\section{Metode Penelitian}

Populasi dalam penelitian ini adalah seluruh mahasiswa yang mendaftar baik pada semester ganjil maupun semester genap tahun akademik 2019/2020. Dan yang menjadi sampel dalam penelitian ini adalah semua populasi. Jumlah mahasiswa yang mendaftar di UNAI pada semester ganjil dan genap 2019/2020 menurut fakultas diberikan pada tabel 1 berikut:

Tabel 1 Jumlah mahasiswa yang mendaftar tahun 2019/2020.

\begin{tabular}{|l|l|l|}
\hline Fakultas & Ganjil & Genap \\
\hline Ekonomi & 816 & 706 \\
\hline Keperawatan & 337 & 328 \\
\hline Teknologi Informasi & 220 & 209 \\
\hline KIP & 120 & 105 \\
\hline Filsafat & 146 & 138 \\
\hline MIPA & 75 & 71 \\
\hline PPS & 38 & 46 \\
\hline Total UNAI & 1762 & 1603 \\
\hline
\end{tabular}

Karena ada mahasiswa yang mendaftar di semester ganjil tetapi tidak mendaftar di semester genap, atau sebaliknya tidak mendaftar pada semester ganjil tetapi kemudian mendaftar di semester genap, maka data Indeks Prestasi Semester (IPS) yang digunakan untuk penelitian adalah data mahasiswa yang mendaftar pada kedua semester, ganjil dan genap tahun akademik 2019/2020, yang berjumlah 1516 orang dengan perincian pada tabel 2 berikut: 
Tabel 2 Jumlah mahasiswa yang mendaftar pada kedua semester ganjil dan genap.

\begin{tabular}{|l|l|}
\hline Fakultas & Jumlah \\
\hline Ekonomi & 686 \\
\hline Keperawatan & 290 \\
\hline Teknologi Informasi & 201 \\
\hline KIP & 104 \\
\hline Filsafat & 133 \\
\hline MIPA & 71 \\
\hline PPS & 31 \\
\hline Total UNAI & 1516 \\
\hline
\end{tabular}

Data yang digunakan untuk penelitian ini adalah Indeks Prestasi Semester (IPS) seluruh mahasiswa UNAI pada semester ganjil dan genap tahun akademik 2019/2020. Data ini telah tersedia secara online dari modul wakil rektor 1 [9]. Data umumnya IPS ini akan bersifat final setelah tanggal terakhir (deadline) pemasukan nilai oleh dosen yang juga dilakukan secara online.

\section{Hipotesis Penelitian}

A. Hipotesis menurut UNAI atau fakultas:

H01: Tidak ada perbedaan rerata IPS mahasiswa di UNAI (atau di setiap fakultas).

Ha1: Ada perbedaan rerata IPS mahasiswa di UNAI (atau di setiap fakutas).

B. Hipotesis menurut tingkat:

H02: Tidak ada perbedaan rerata IPS antara mahasiswa I, atau II, atau III atau Senior.

Ha2: Ada perbedaan rerata IPS antara mahasiswa I, atau II, atau III atau Senior.

C. Hipotesis menurut jenis kelamin:

H02: Tidak ada perbedaan rerata IPS antara mahasiswa pria dengan wanita.

$\mathrm{Ha}$ 2: Ada perbedaan rerata IPS antara mahasiswa pria dengan wanita.

Pengujian hipotesis dilakukan dengan membandingkan nilai signifikansi ( $p$-value) dari hasil olahan data IPS dengan nilai tingkat kepercayaan atau alpha $(\alpha)$.

\section{Anggapan Dasar}

Pada penelitian ini diberikan dua anggapan dasar sebagai berikut:

1. Pandemi Covid-19 akan berdampak negatif pada prestasi belajar mahasiswa, ini disebabkan perubahan yang tiba-tiba dalam model pembelajaran. Perubahan cenderung berdampak negatif pada prestasi belajar mahasiswa, karena mahasiswa memerlukan waktu untuk beradaptasi.

2. Setiap perubahan dalam indeks prestasi semester mahasiswa UNAI pada masa pandemi Covid-19 (semester genap 2019/2020) dianggap diakibatkan oleh perubahan model pembelajaran, yang tadinya tatap muka di kelas menjadi daring atau dianggap sebagai akibat langsung dari pandemi covid-19.

\section{Hasil}

\section{IPS Menurut Fakultas}

Rerata indeks prestasi semester mahasiswa UNAI dan menurut fakultas diberikan pada tabel 3 berikut. Secara umum dapat dilihat bahwa untuk level universitas ada kenaikan yang cukup signifikan rerata IPS mahasiswa. Kenaikan IPS mahasiswa pada semester genap hanya sebesar 0,06 (atau sekitar 1,9\%), namun karena simpangan baku IPS pada semester ganjil dan genap hampir sama dan cukup kecil yaitu 0,42 dan 0,48), maka kenaikan $2 \%$ tersebut menjadi 
signifikan. Jika dibandingkan IPS menurut fakultas, Fakultas Ekonomi dan Keguruan Ilmu Pendidikan, sedangkan untuk fakultas lain (Keperawatan, Teknologi Informasi, Filsafat, MIPA dan Pasca Sarjana) mengalami kenaikan. Namun penurunan IPS pada fakultas ekonomi dan Keguruan Ilmu Pendidikan tidak signifikan, demikian halnya pada program pasca sarjana yang mengalami kenaikan tetapi tidak signifikan, sedangkan fakultas lain mengalami kenaikan yang signifikan.

Tabel 3 Rerata IPS pada semester ganjil dan genap 2019/2020 menurut UNAI dan Fakultas.

\begin{tabular}{|l|l|l|l|l|}
\hline Fakultas & Ganjil & Genap & Nilai sig. (one tail) & Catatan \\
\hline Ekonomi & 3,20 & $3,18 \downarrow$ & 0,093 & Turun tetapi Tidak signifikan \\
\hline Keperawatan & 3,25 & $3,44 \uparrow$ & $7,18 \mathrm{e}-10$ & Naik Signifikan \\
\hline Teknologi Informasi & 3,12 & $3,22 \uparrow$ & 0,014 & Naik Signifikan \\
\hline KIP & 3,21 & $3,10 \downarrow$ & 0,028 & Turun tetapi tidak signifikan \\
\hline Filsafat & 3,14 & $3,32 \uparrow$ & $2,771 \mathrm{e}-9$ & Naik Signifikan \\
\hline MIPA & 3,42 & $3,47 \uparrow$ & 0,023 & Naik Signifikan \\
\hline PPS & 3,40 & $3,73 \uparrow$ & 0,029 & Naik tetapi tidak signifikan \\
\hline UNAI & 3,21 & $3,27 \uparrow$ & $9,315 \mathrm{e}-06$ & Naik Signifikan \\
\hline
\end{tabular}

Terjadinya kenaikan IPS yang cukup signifikan pada fakultas tertentu dapat mengindikasikan bahwa dosen dan mahasiswa cepat beradaptasi dengan model pembelajaran daring, sedangkan fakultas lain yang mengalami penurunan, walau tidak signifikan, mengalami kendala untuk menyesuaikan diri baik dari sisi mahasiswa maupun dosen dalam model pembelajaran daring.

\section{IPS Mahasiswa Menurut Tingkat}

Pada tabel 4 diberikan data rerata IPS pada semester ganjil dan genap 2019/2020. Dilihat pada tabel 4 bahwa ada kenaikan IPS mahasiswa pada semester genap dibanding IPS semester ganjil, kecuali untuk mahasiswa tingkat I, yang terjadi adalah sebaliknya dimana rerata IPS semester genap menurun dibanding semester ganjil, walau rerata penurunan tersebut hanya sekitar $0,8 \%$. Penurunan atau kenaikan rerata IPS dianggap adalah pengaruh dari perbedaan metode pembelajaran yang dialami mahasiswa, dimana pada paruh kedua semester genap, setelah pertengahan Maret 2020, metode pembelajaran adalah daring selama pandemi Covid-19.

Tabel 4 Rerata IPS menurut angkatan pada semester ganjil dan genap 2019/2020.

\begin{tabular}{|l|l|l|l|l|l|l|}
\hline Angkatan & Ganjil & Genap & Genap-ganjil & \% & p-value & Catatan \\
\hline 2019 & 3,316 & 3,291 & $-0,025$ & $-0,8 \%$ & 0,258 & Tidak signifikan \\
\hline 2018 & 3,245 & 3,264 & 0,019 & $0,6 \%$ & 0,405 & Tidak signifikan \\
\hline 2017 & 3,239 & 3,366 & 0,127 & $3,9 \%$ & 0,000 & Signifikan \\
\hline Senior & 2,966 & 3,127 & 0,161 & $5,4 \%$ & 0,000 & Signifikan \\
\hline
\end{tabular}

Dari fakta bahwa mahasiswa baru (tingkat 1 ) mengalami penuruan sekitar $0,8 \%$ tetapi pada tingkat 2,3 dan 4 (atau mahasiswa senior) justru mengalami kenaikan, dan kenaikan terbesar $(5,4 \%)$ terjadi pada tingkat senior, ini membuktikan bahwa mahasiswa baru mengalami kendala dengan system pembelajaran online, sedangkan tingkat 2, 3 dan senior cepat menyesuaikan diri dengan model pembelajaran yang baru. Tahun pertama perkuliahan adalah masa dimana masa bagi mahasiswa menyesuaikan diri dengan pembelajaran di perguruan tinggi, yang agak berbeda dengan di sekolah menengah. Menurut observasi pada mahasiswa UNAI, tingkat drop out terbesar terjadi pada tahun pertama perkuliahan. Bagi sebagian mahasiswa, tahun pertama perkuliahan adalah masa mencoba program studi yang sesuai dengan minat dan bakatnya. Jika ternyata ada kendala dalam perkuliahannya maka mahasiswa akan pindah ke program studi lain di UNAI atau pindah ke perguruan lain. 


\section{IPS Mahasiswa Pria vs. Wanita}

Rerata Indeks prestasi semester (IPS) mahasiswa pria dan wanita pada semester ganjil dan genap 2019/2020 dan data-data untuk uji statistiknya ditunjukkan pada tabel 5 dan 6.

Tabel 5 Uji rerata IPS mahasiswa Pria UNAI pada semester ganjil dan genap 2019/2020.

t-Test: Paired Two Sample for Means

\begin{tabular}{lll}
\hline Pria & Ganjil & Genap \\
\hline Mean & 3,064532 & 3,142429 \\
Variance & 0,584156 & 0,634554 \\
Observations & 737 & 737 \\
Pearson Correlation & 0,694508 & \\
Hypothesized Mean Difference & 0 & \\
df & 736 & \\
t Stat & $-3,46244$ & \\
P(T<=t) one-tail & 0,000283 & \\
t Critical one-tail & 1,646927 & \\
P(T<=t) two-tail & 0,000566 & \\
t Critical two-tail & 1,963192 & \\
\hline
\end{tabular}

Dari tabel 5 di atas rerata IPS mahasiswa pria pada semester ganjil adalah 3,065, sedangkan pada meningkat menjadi 3,142 pada semester genap atau naik sekitar 2,5\%. Dengan melihat nilai signifikansi $(p)=0,0003$ ini jauh lebih kecil dari nilai a/2 (0,025), dengan demikian dapat disimpulkan bahwa rerata IPS mahasiswa Pria pada semester ganjil dan semester genap berbeda, dimana pada semester genap rerata IPS meningkat.

Fenomena ini juga terjadi pada mahasiswa wanita, seperti ditunjukkan pada data pada tabel berikut. Dapat dilihat bahwa rerata IPS mahasiswa wanita pada semester ganjil adalah 3,349, sedangkan pada pada semester genap menjadi 3,388, atau naik sebesar $1,2 \%$. Dari uji hipotesis, dengan melihat nilai signifikansi $(p)=0,0058$ dan membandingkannya dengan nilai $a / 2(0,025)$, dapat disimpulkan bahwa rerata IPS ini berbeda dimana rerata IPS mahasiswa wanita pada semester genap meningkat dibandingkan pada semester ganjil.

Tabel 6 Uji rerata IPS mahasiswa wanita UNAI pada semester ganjil dan genap 2019/2020.

t-Test: Paired Two Sample for Means

\begin{tabular}{lll}
\hline Wanita & Ganjil & Genap \\
\hline Mean & 3,348816 & 3,388263 \\
Variance & 0,225997 & 0,308278 \\
Observations & 777 & 777 \\
Pearson Correlation & 0,654857 & \\
HypothesizedMean Difference & 0 & \\
df & 776 & \\
t Stat & $-2,53208$ & \\
$\mathrm{P}(\mathrm{T}<=\mathrm{t})$ one-tail & 0,005767 & \\
t Critical one-tail & 1,64682 & \\
$\mathrm{P}(\mathrm{T}<=\mathrm{t})$ two-tail & 0,011535 & \\
$\mathrm{t}$ Critical two-tail & 1,963026 & \\
\hline
\end{tabular}


Dari tabel 5 dan 6 dapat dilihat bahwa IPS mahasiswa wanita lebih tinggi (baik) dari mahasiswa pria. Perbedaan IPS antara wanita dan pria bukan akibat pandemi covid, bahkan sebelum pandemi covid-19 didapati bahwa prestasi akademik mahasiswa wanita UNAI lebih tinggi dari pria. Namun perbedaan rerata IPS mahasiswa pria pada semester genap dan ganjil $(0,078)$ sedikit lebih baik dari mahasiswa wanita $(0,040)$. Fakta bahwa wanita prestasi belajar mahasiswa wanita lebih baik dari pria ini sesuai dengan penelitian sebelumnya [9]. Salah satu penyebab prestasi belajar wanita lebih baik disbanding pria adalah karena wanita lebih rajin dan lebih menurut dari pria. Namun pada masa pandemi covid-19 ini sekalipun prestasi belajarnya sama-sama meningkat namun peningkatan IPS mahasiswa pria sedikit lebih besar dari wanita. Temuan ini dapat menunjukkan bahwa sepertinya pria lebih kreatif dalam menyesuaikan diri terhadap model pembelajaran daring selama pandemi, itu sebabnya peningkatan IPS lebih besar.

\section{Pembahasan/Kesimpulan}

Secara umum rerata IPS mahasiswa UNAI meningkat pada semester genap (masa pendemi covid-19) dibanding IPS semester ganjil (sebelum pandemi). Namun bila dilihat data IPS pada setiap fakultas, tidak semua fakultas mengalami kenaikan, bahkan ada dua fakultas, yaitu Ekonomi dan Keguruan dan Ilmu Pendidikan, justru mengalami penurunan walau tidak terlalu signifikan, yang diakibatkan oleh perubahan yang tiba-tiba dari model pembelajaran dari tatap muka di kelas menjadi daring atau diakibatkan oleh pandemi covid-19.

Pandemi Covid-19 membawa dampak negatif hanya pada mahasiswa tahun pertama (baru) saja, sedangkan pada tingkat 2, 3 dan senior pandemi covid-19 justru membawa dampak yang sedikit positif, dengan kenaikan rerata IPS sekitar $1 \%$ hingga 5\%. Ini dapat menunjukkan bahwa mahasiswa tingkat 2, 3 dan senior lebih cepat menyesuaikan diri dengan perubahan yang tiba-tiba dalam model pembelajaran.

Ada kenaikan yang signifikan IPS mahasiswa baik pria maupun wanita pada semester genap dibanding pada semester ganjil, walau persentase kenaikan pada mahasiswa pria sedikit lebih besar dari wanita $(2,5 \%$ pada pria atau $1,2 \%$ pada wanita). Ini menunjukkan bahwa pria lebih kreatif dalam penyesuaian diri pada model pembelajaran daring.

Penelitian ini perlu dilanjutkan pada semester yang akan datang, ganjil 2020/2021, untuk melihat dampak pembelajaran daring akibat pandemi covid-19 dalam jangka panjang. Apakah peningkatan prestasi belajar mahasiswa UNAI bersifat jangka panjang atau hanya sementara. Di samping itu perlu dikaji lebih dalam dengan membuat survei kepada mahasiswa atau dosen untuk mengetahui lebih detil tentang halhal yang terjadi di lapangan selama pembelajaran daring (untuk melihat factor-faktor langsung) sehingga diketahui alasan yang sebenarnya dibalik peningkatan prestasi belajar tersebut.

\section{Referensi}

[1] Limbong, A., Pengaruh Bakat dalam Pencapaian Akademik Mahasiswa UNAI, Teika, vol. 9(2), 2019.

[2] Slameto, Belajar dan Faktor-faktor yang Mempengaruhinya, Jakarta:Rineka Cipta, 1995:125.

[3] Djamarah, dkk., Strategi Belajar Mengajar, Jakarta:Rineka Cipta, 2000:8.

[4] Sujatmika, S. dkk., Pengaruh Metode Pembelajaran Problem Based Learning Terhadap Prestasi Belalar, Sosiohumaniora, Vol. 2(1), 2016.

[5] 220 Ali Sadikin. A. dkk., Pembelajaran Daring di Tengah Wabah Covid-19, BIODIK: Jurnal Ilmiah Pendidikan Biologi, vol. 6(2), 2020.

[6] Wijaya, R. dkk., Dampak pandemi Covid19 terhadap pemanfaatan e-learning, Dimensi, 9(2), 2020.

[7] Pratiwi, E.W., Dampak Covid-19 terhadap kegiatan pembelajaran online di sebuah Perguruan Tinggi Kristen di Indonesia, Perspektif Ilmu Pendidikan, vol. 34(1), 2020. 
[8] Kusnayat, A., Pengaruh Teknologi Pembelajjaran Kuliah Online di era Covid-19 dan dampaknya terhadap mental mahasiswa, Edukasi dan Teknologi Pembelajaran, vol. 1(2), 2020.

[9] Universitas Advent Indonesia, http://online2.unai.edu/pr1/welcome.php, data diunduh pada sekitar bulan Agustus 2020.

[10] Limbong, A., Siahaan, M. A Study of Information Technology (IT) graduate performance based on gender, study program and batches, Proceedings of 1st International Scholars Conference, AIU Bangkok, 2013:156-173. 